the deep appreciation of this generation for their work in the past.

The report of the afternoon proceedings before the joint session of the Fiftieth General Assembly will be given in a later issue of this publication.

From many sources came the comment that the Twenty-eighth biennial session was most satisfactory. The program was carried through with precision. Members enjoyed visiting with old friends and recounting past experiences.

\title{
AN IOWA INTERNATIONAL SUGGESTION
}

In his talk at the meeting of the Iowa Pioneer Lawmakers Association in February 1943, Senator Geo. M. Titus of Muscatine, referred to his proposals for an international monetary agreement, and upon inquiry it was found he had embodied them in the following memorandum:

1. An international nonprofit bank supported at first by England, United States and Russia.

2. Located in this country because we have, I understand, $80 \%$ or more of the gold of the world.

3. The facilities of this bank open only to nations who will stabilize their currencies in conformity with the regulations of the bank.

4. The charges of the bank only sufficient to pay expenses and properly conduct the same. This would indicate to all nations that the bank was established to facilitate international trading.

5. Since the business of three-fourths of the world is done with silver only, gold should be the base but gold and silver on some reasonable ratio should be used.

6. If this were done, it would, in my judgment, secure greater world prosperity than has hitherto been known.

7. In my judgment, the postwar money question is the most important problem for solution.

8. It would probably be necessary for this country to pledge some portion of its gold reserve to stabilize its interest in the international bank.

9. In my judgment, it would be very desirable if the suggestion for such a bank would come from England.

10. This whole money question should be acted upon in a nonpartisan way. In other words, the solution should be on the part of both democrats and republicans in this country. 
Copyright of Annals of Iowa is the property of State of Iowa, by \& through the State Historical Society of Iowa and its content may not be copied or emailed to multiple sites or posted to a listserv without the copyright holder's express written permission. However, users may print, download, or email articles for individual use. 